\title{
RARalpha Agonist IRX5183
}

National Cancer Institute

\section{Source}

National Cancer Institute. RARalpha Agonist IRX5183. NCI Thesaurus. Code C77899.

An orally bioavailable retinoid acid receptor alpha (RARalpha) agonist and vitamin A derivative, with potential antineoplastic activity. Upon administration, RARalpha agonist IRX5183 binds to and activates RARalpha, which promotes RARalpha-mediated signaling. This results in the transcription of RARalpha-responsive genes, which are responsible for cellular differentiation and proliferation. This results in the induction of cellular differentiation and apoptosis, and leads to the inhibition of cellular proliferation and tumorigenesis. RARalpha is a nuclear receptor and a member of the steroid receptor superfamily; reduced RARalpha signaling is correlated with cancer development in a variety of cancer cell types. 